\title{
HEPARAN SULFATE AND CHONDROITIN SULFATE: GENERAL ASPECTS OF THEIR PARTICIPATION DURING Plasmodium falciparum DEVELOPMENT
}

\author{
Erika Francisca Garrido Zea ${ }^{1,2}$ \\ Raul Leonardo Rocha Orjuela1,2 \\ Luis Carlos Burgos Herrera ${ }^{1,2}$
}

\begin{abstract}
Background: Malaria is one of the most important infectious diseases worldwide due to its high morbidity and mortality rates every year in tropical countries. Despite efforts in malaria research, several mechanisms underlying hostparasite interactions remain unclear, which is a big obstacle for the management and control of malaria.

Recently, numerous studies have attempted to provide a better understanding of the physiopathological mechanisms to assist in the design of new drugs, vaccines and transmission blocking agents. These research topics have indicated that glycans are key molecules in the life cycle of the malarial parasites.

The aim of this review is to highlight the relevance of glycans for the development and transmission of Plasmodium and to use that information as a valuable research tool to fight malaria.
\end{abstract}

Because glycans play roles in parasite invasion and interactions with the mosquito host, both of which are part of "parasite development", this review seeks to specify the role of glycans in parasite development.

Methods: This review was mainly based on research articles published between 1985 and 2015 that were obtained from the PubMed and Embase databases. The keywords used in this search were sulfated glycans, malaria, Anopheles and Plasmodium.

Conclusions: Sulfated glycoconjugates are intimately linked to the development, transmission and survival of Plasmodium in the intermediate and definitive hosts. A better understanding of the role of sulfated glycoconjugates in malaria infection would permit the development of new therapeutic strategies and the design of strategies to inhibit parasite transmission.

Key words: sulfated glycans, malaria, mosquitoes, Plasmodium.

\footnotetext{
${ }^{1}$ Biomedical Research Group UniRemington, Medicine Programe, Faculty of Health Sciences, Corporación Universitaria Remington, Medellín, Colombia

2 Department of Physiology and Biochemistry, Faculty of Medicine, Universidad de Antioquia, Medellín, Colombia Luís Carlos Burgos Herrera, Medellín - Colombia - Suramérica Icburgos@gmail.com

Raúl Leonardo Rocha, Medellín - Colombia- Suramérica

raul.rocha@uniremington.edu.co

Authors for correspondence: Erika Francisca Garrido, Medellín - Colombia- Suramérica

erikafgz@gmail.com or erika.garrido@uniremington.edu.co

Funding statement

This work was supported by Faculty of Health Sciences of Corporación Universitaria Remington.
} 
Heparan sulfate and chondroitin sulfate: general aspects of their participation during Plasmodium falciparum...

\section{SULFATO DE HEPARÁN Y SULFATO DE CONDROITINA: ASPECTOS GENERALES DE SU PARTICIPACIÓN DURANTE EL DESARROLLO DE Plasmodium falciparum}

\section{RESUMEN}

La malaria es considerada una de las enfermedades infecciosas de mayor importancia alrededor del mundo debido a la alta morbimortalidad que causa cada año en países tropicales. A pesar de los esfuerzos de investigación en malaria, muchos de los mecanismos que entrañan las interacciones hospedero-parásito aún no son claros, lo que constituye un gran obstáculo en el manejo y control de la malaria.

Numerosos estudios se han llevado a cabo en los últimos años en busca de una mejor comprensión de los mecanismos fisiopatológicos, diseño de nuevas drogas, diseño de una vacuna y bloqueo de la transmisión. En todos estos temas de investigación, un elemento común son los glicanos

\section{INTRODUCTION}

Malaria is an important infectious disease that has a huge impact on the health of millions of people who inhabit the tropical and subtropical zones of the planet. The treatment and eradication of malaria entail an enormous effort by research organizations, which are always seeking new strategies to achieve a better understanding of the disease. The malaria problem can be approached from different aspects (drugs resistance, some physiopathological aspects and transmission). Many research studies have been dedicated to the design of new drugs to combat the disease based on knowledge of the metabolic pathways of the parasite, which has revealed several enzymes as molecular targets. However, the results have not represented definitive successes in the solution to this problem $(1,2)$. como moléculas clave en el ciclo de vida de los parásitos de la malaria.

El objetivo de esta revisión es mostrar como los glicanos se necesitan para el desarrollo y la transmisión de Plasmodium y como esta información resulta ser una valiosa herramienta en la investigación para combatir la malaria.

Métodos: La presente revisión se basó principalmente en artículos originales publicados entre 1985 y 2015, obtenidos de las bases de datos PubMed y EmBase. La búsqueda fue hecha en inglés y se usaron las palabras clave: glicanos sulfatados, malaria, Anopheles y Plasmodium.

Conclusión: Los glicoconjugados sulfatados están íntimamente vinculados al desarrollo, la transmisión y la supervivencia de Plasmodium, tanto en el hospedero intermediario como en el hospedero definitivo. Una mejor comprensión del rol de los glicoconjugados sulfatados en la infección malárica permitiría el desarrollo de nuevas alternativas terapéuticas, así como el diseño de estrategias para inhibir la transmisión.

Palabras clave: glicanos sulfatados, malaria, mosquitos, Plasmodium.

Some studies have addressed the problem from a different perspective and sought to understand the biology of the malaria parasites. This approach also represents a great challenge because Plasmodium falciparum is not a conventional parasite. Instead, P. falciparum diverges significantly from other eukaryotic organisms and has developed a battery of genes (var genes) that permit diverse antigenic repertoire to permanently evade the host immune response $(3,4)$.

To date, many parasite proteins have been described $(5,6)$, and their participation has been documented in various events that are important for the survival of the parasite, such as invasion and adherence. However, recent glycobiology studies have revealed the importance of sulfated glycoconjugates and their relationship with malaria $(7,8)$. 
Current investigations aim to demonstrate that these compounds are critical for Plasmodium development during different stages of the parasite's life cycle in both the definitive host (the mosquito) and the intermediate host (the vertebrate). Additionally, these compounds are necessary for the invasion and adhesion processes (9-12).

This review aims to highlight the importance of sulfated glycoconjugates (glycosaminoglycans (GAGs) and proteoglycans) during the development of Plasmodium in both the mosquito and the vertebrate host and thereby motivate researchers to undertake studies regarding this topic. These studies will aid in the development of a better understanding of the pathophysiology of malaria infection and consequently contribute to the development of new strategies to control this infection.

\section{Plasmodium life cycle}

The Plasmodium life cycle is complex and alternates between a definitive host (mosquito) where the sexual phase occurs and the intermediate host (a vertebrate) where the asexual phase occurs. The life cycle starts when a female Anopheles-infected mosquito releases sporozoites into the bloodstream of a human. This form of the parasite invades the liver. At this stage, the parasite adopts an intracellular lifestyle and multiplies into hundreds of invasive forms called merozoites. These merozoites invade erythrocytes and give rise to the preerythrocytic and exo-erythrocytic stages. The merozoites maintain the intra-erythrocytic cycle by invading non-infected red cells. A small proportion of the merozoites grow inside the erythrocytes into either a female or male gametocyte, which will be consumed in a blood meal by a female mosquito. After a process called exflagellation, the male gametocytes convert into flagellated forms called microgametes, which fertilize the macrogametes, resulting in a zygote. This parasite stage progresses to an ookinete. After penetrating the mosquito gut wall, the oocyst appears and multiplies by an asexual mechanism into hundreds of motile forms called sporozoites that reach the salivary glands. The sporozoites will be released during a new blood meal by the female mosquito, and the cycle starts again to guarantee parasite transmission (13).

\section{Sulfated glycoconjugates in living organisms}

GAGs are the most abundant heteropolysaccharides in organisms and are arranged in long branched chains that consist of repeating disaccharide units, including $\mathrm{N}$-acetylglucosamine (GlcNA) or N-acetylgalactosamine (GalNAc) and glucuronate or iduronate. Sulfated glycans exhibit a high density of negative electrical charges due to the presence of many sulfate groups $\left(-\mathrm{SO}_{4}^{-2}\right)$, which confer different properties depending on their amount and location $(14,15)$. These molecules are abundant in the extracellular matrix, where they behave as molecular mechanical shock absorbers due to their hygroscopic nature and low compressibility (15); additionally, these molecules are found on the surface of every cell in the organism and form part of the glycocalyx, which creates a permissive microenvironment for functions such as cellular differentiation, adhesion and physiological and pathological signaling events $(16,17)$. Glycoconjugates are quintessential communication molecules for these functions (18).

\section{Glycoconjugates, ABO blood group,} Plasmodium falciparum and severity

In the evolutionary history of Plasmodium falciparum and humans, the parasite first appeared approximately 200 million years ago, whereas Homo sapiens appeared only 200,000 years ago. Between 100,000 and 40,000 years ago, the first human group migrations from Africa to Oceania, Europe and Asia occurred. The ABO blood group polymorphisms that developed under pressure by Plasmodium falciparum were carried with these individuals (19). When the 
$\mathrm{ABO}$ group appeared in the human population, the parasite selected individuals with blood group O because this group conferred a survival advantage for the human population that was not present in the $\mathrm{A}, \mathrm{B}$ and $\mathrm{AB}$ blood groups (20). Studies in 2007 found that the severity of malaria appeared to be related to the $\mathrm{A}, \mathrm{B}$ or $\mathrm{AB}$ blood groups, whereas a minority of complications occurred in individuals in the $\mathrm{O}$ blood group $(19,20)$. Studies of the geographical distribution of blood group polymorphisms in areas where malaria is endemic are just beginning to emerge $(20,21)$.

The above finding seems to be related to the fact that blood groups are classified according to the antigens present on erythrocytes. These antigens correspond to chains of monosaccharides (GalNAc or D-galactose) that carry sialic acid in the terminal positions of the glycan. Individuals in the $\mathrm{O}$ blood group lack surface antigens, which may explain why the invasion process is minimal in patients in this blood group; Plasmodium falciparum erythrocyte membrane protein 1 (PfEMP1) presents domains that recognize surface antigens during the initiation of the adhesion and invasion processes (20).

Heparan sulfate and chondroit in sulfate mediate Plasmodium falciparum invasion and adhesion

Glycans such as heparan sulfate (HS) and chondroitin sulfate (CS) have been identified to play roles during the Plasmodium falciparum adhesion and invasion processes. HS has been found in endothelial cells, on the surface of erythrocytes and on the surface of sporozoites $(14,17)$. CS is expressed in numerous cells in the body, although a variety of this glycan that serves as a Plasmodium parasite receptor occurs exclusively in syncytiotrophoblast cells in pregnant women (21).

\section{Formation of the invasive phenotype}

Following inoculation of sporozoites into the skin or bloodstream of vertebrates by the infected mosquito, the parasites migrate to the liver and establish this organ as an obligatory pathway for Plasmodium spp. However, why the parasite follows this route is unknown $(22,23)$.

Studies in which sporozoites are cultured have been performed in the following cell lines: Chinese hamster ovary cells $(\mathrm{CHO})$, endothelial cells (HBMVEC), dermal fibroblasts (MDF) and liver cells (Hepa1-6); the degrees of surface HS sulfation in these cell lines are known. The experiments consisted of altering the concentration of sulfate in the HS molecule prior to sporozoite culture. Additionally, soluble heparin assays were performed at different concentrations to verify the degree of inhibition of sporozoite invasion in the sulfated cells.

The results demonstrated that the degree of HS sulfation present in the hepatocytes was greater than the degree of HS sulfation on other cells in the body and that the concentration of sulfate played a determinant role in the development of an invasive phenotype of the parasite by preparing the parasite for the subsequent invasion of erythrocytes. The sporozoites only migrated through cells with low HS sulfation and only invaded cells with highly sulfated HS. However, soluble heparin proved not to be a competitive inhibitor of cell invasion by the sporozoites (24).

\section{Rosette formation and sequestration}

In malaria, one event that greatly contributes to the development of complications is the phenomenon of cytoadherence (17), which involves sequestration (i.e., the adhesion of the parasitized erythrocytes to the endothelium of the microvasculature of various organs) and rosetting or the formation of rosettes, which consists of the adhesion of parasitized erythrocytes to other healthy erythrocytes or other blood cells. Both events lead to obstruction of the microvasculature and trigger a state of tissue hypoxia and eventually organ failure ( 7 , 8). 
The adherence of parasitized erythrocytes involves several molecules, including PfEMP1, which is exported by Plasmodium parasites to the surface of the erythrocyte and presents several domains that adhere to molecules present on the host cell surface, such as intercellular adhesion molecule 1 (ICAM1), CD36 and HS and CS proteoglycans $(25,26)$. However, studies conducted by Fried and Duffy in 1996 showed that CS exclusively participated in the sequestration of erythrocytes parasitized by Plasmodium falciparum in the placenta (27). Another study by Valiyaveettil et al. in 2001 suggested that hyaluronic acid (HA), which is a non-sulfated glycan, was a potential receptor for parasitized red blood cells ( $\mathrm{pRBCs}$ ) in the placenta (28).These results were confirmed by Beeson et al. (29). Different types of CS exist; only chondroitin sulfate A (CSA) and chondroitin-4-sulfate (C4S) are responsible for sequestration in the placenta because these forms are expressed in the placental extracellular matrix and syncytiotrophoblast cells (21, 27, $30)$. These events are intimately related to the pathophysiology and complications of the disease. There is evidence of a DBLX-2 domain in the Plasmodium falciparum var 2CSA protein that constitutes the CSA binding site; thus, var 2CSA is a strong vaccine candidate (9).

In vitro assays conducted with different HS and CS glycans and modified heparin (with variations in the degree of sulfation and the position of the sulfate groups) have shown that the formation of rosettes can be reversed in cultured laboratory strains (FCR3S1) and wild isolates when HS and CS glycans are introduced into the cultures. However, wild isolates exhibit some adhesion preferences (31) (i.e., there is a delicate regulation within this interaction, which makes some strains more adherent than others depending on the subtle variations present in the distribution and concentration of sulfated glycans on vertebrate cells (32)). Another important potential role of sulfated glycans such as CSA and HS is their regulatory activity on placental inflammation as a result of the parasite presence (33).

\section{Heparan sulfate and chondroitin sulfate in the mosquito-parasite interaction}

The parasite passes through two tissue types during its development in the mosquito vector. The first obligatory pathway involves binding of the ookinetes to the basement membrane of the mosquito's intestinal epithelium, followed by invasion by the sporozoites to the salivary glands.

A critical interaction between the ookinetes and intestinal cells is mediated by GAGs, including CS, which are located on the basement membrane proteoglycans of the mosquito's intestinal epithelium. The importance of this interaction has been demonstrated in Anopheles gambiae, where $95 \%$ inhibition of ookinete invasion of the middle intestine has been shown (34). Additionally, other studies have suggested that the parasite uses not only the GAGs of CS but also of HS to locate the target organs and for development during different life cycle stages in the vector and the vertebrate host (Fig. 1) $(10,11)$.

Whether the composition and quantity of the GAGs are the same in cells from different Anopheles species with different vectorial conditions of natural populations and how these differences influence malaria transmission are unknown. The answer to this question will allow the determination of key aspects of the development of strategies aimed at vector control and decreasing malaria transmission. Vaccine design was thought to represent a good strategy to block malaria transmission. In 2015, the Anopheles monoclonal (mAb) antiaminopeptidase-N antibody (An APN1) 4H5B7 was shown to recognize AnAPN1, which is the Plasmodium ookinete receptor in the mosquito midgut (35). The identity of the GAGs involved in the interaction are unknown at present, and their identification will contribute to vaccine design. The possible GAGs involved in this interaction need to be identified to contribute to vaccine development. 


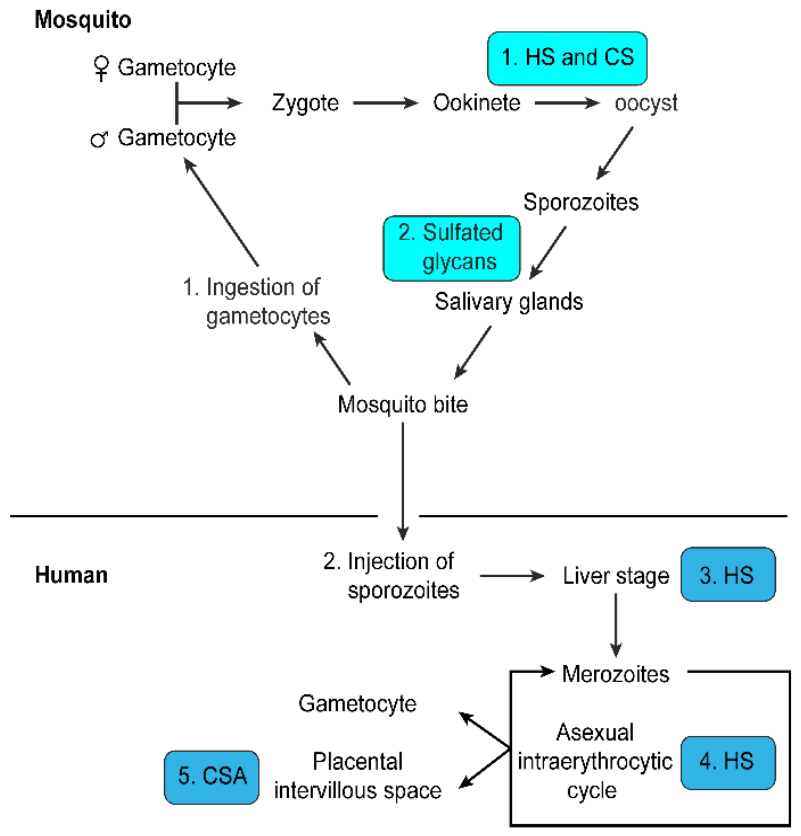

Figure 1. Function of glycans in the life cycle of Plasmodium spp.

\begin{abstract}
Figure captions
Fig. 1 Function of glycans in the Plasmodium spp. life cycle in the definitive host (mosquito) and the intermediate host (vertebrate/human). 1. Heparan sulfate (HS) and chondroitin sulfate (CS) are necessary for the maturation of the ookinete to the oocyst. 2. Sulfated glycoconjugates mediate the arrival of sporozoites into the mosquito salivary glands. 3 . HS induces the hepatic stages of Plasmodium spp. that initiate the formation of an invasive phenotype capable of infecting red blood cells (RBCs). 4 . HS mediates rosette formation and the adherence of the parasitized erythrocytes to the endothelium of the microvasculature of deep organs. 5. Chondroitin sulfate A (CSA) is the principal mediator of the adherence and sequestration of parasitized maternal RBCs in the intervillous space of the placenta during placental malaria.
\end{abstract}

Glycosylation enzymes in Plasmodium falciparum

In 2002, the genome of Plasmodium falciparum was sequenced, and the parasite was found to lack glycosylation enzymes (3). However, in 2007, a study conducted by Landoni et al. (36) revealed that the parasite performed sulfo glycosphingolipid synthesis in three different stages. In addition to requiring glycosylation enzymes for their synthesis, these compounds are important for stabilizing the membrane of the parasite and may be involved in the invasion phenomenon. Additionally, a different sulfo glycosphingolipid biosynthesis process was found for each of the three intraerythrocytic stages (ring, trophozoite and schizont), suggesting the possibility of different levels of sulfation throughout the parasite's life cycle. Another event that has been reported in the intraerythrocytic stages is the synthesis of glycophosphatidylinositol, for which the parasite requires the glycosylation enzyme dolichol phosphate mannose (37).

Some technical difficulties must still be overcome to identify the glycosylation enzymes in Plasmodium. This process requires very sensitive analytical methods and the choice of a synchronous culture in a mature stage 
(trophozoites) because this stage is "where instead of that" that Plasmodium exhibits most of its proteins. Experimental strategies must be designed to eliminate the possibility of contamination by host molecules because Plasmodium is an obligate intracellular parasite.
To date, a portion of the saccharide complexsynthesis capacity of the parasite has been outlined. Furthermore, the parasite contains lectins that enable interactions with both the vector and the intermediate host (8) (Table 1).

Table 1. Structure, role, receptor and function of sulfated glycans during the infection by Plasmodium falciparum.

\begin{tabular}{|c|c|c|c|}
\hline $\begin{array}{c}\text { Sulfated } \\
\text { Glycan }\end{array}$ & $\begin{array}{c}\text { Rol during } \\
\text { infection }\end{array}$ & Chemical structure & Receptor in the parasite \\
\hline $\begin{array}{l}\text { Heparan } \\
\text { sulfate (HS) }\end{array}$ & $\begin{array}{l}\text { - Adhesion in } \\
\text { endothelium and } \\
\text { rosetting } \\
\text {-Development of an } \\
\text { invasive phenotype } \\
\text { in the liver } \\
\text { - Motility and } \\
\text { invasion in the } \\
\text { mosquito midgut } \\
\text { and salivary glands } \\
\text { *Maturation of } \\
\text { ooquinetes }\end{array}$ & $\mathrm{OR}_{3}$ & $\begin{array}{l}\text { PfEMP-1 protein } \\
\text { (DBL- } \alpha \text { domain) - } \\
\text { human infection/ CSP } \\
\text { and TRAP proteins in } \\
\text { mosquito infection }\end{array}$ \\
\hline $\begin{array}{l}\text { Chondroitin } \\
\text { sulfate (CS) }\end{array}$ & $\begin{array}{l}\text { - Motility and } \\
\text { invasion in the } \\
\text { mosquito midgut } \\
\text { and salivary glands } \\
\text { *Maturation of } \\
\text { ookinete }\end{array}$ & & $\begin{array}{l}\text { CSP and TRAP proteins } \\
\text { - only in mosquito } \\
\text { infection }\end{array}$ \\
\hline $\begin{array}{l}\text { Chondroitin } \\
\text { sulfate A } \\
(\mathrm{CSA})\end{array}$ & $\begin{array}{l}\text {-Sequester in the } \\
\text { syncytiotrophoblast } \\
\text { *Regulation of } \\
\text { the placental } \\
\text { inflamation }\end{array}$ & & $\begin{array}{l}\text { VAR2CSA protein - only } \\
\text { in placental infection }\end{array}$ \\
\hline
\end{tabular}

*Information non-confirmed yet.

\section{Sulfated glycans as antimalarial therapies}

Sulfated GAGs, such as heparin, CSA and HS, have been proposed as potential antimalarial therapies because these glycans can inhibit adhesion phenomena in pRBCs when soluble (38). Heparin was used as a treatment for severe malaria years ago but was abandoned due to its potent anticoagulant action and adverse effects, such as intracranial bleeding (8).

Recent studies have shown that depolymerized heparin that lacks anticoagulant activity can maintain its ability to function as an inhibitor 
for pRBC sequestration and rosette disruption not only in vitro but also in vivo in fresh parasite isolates (38).

An important property of heparin is its ability to penetrate pRBCs. Furthermore, heparin can easily be conjugated to drug-containing nanovessels while preserving its antimalarial effect. These ideas may provide a new costeffective pharmacotherapy in the socioeconomic context of malaria (39).

Based on the above findings, heparin still remains at the spearhead of GAGs with antimalarial activity and may be considered a targeting molecule for the localized delivery of drugs to Plasmodium-infected cells. However, further research is required in that particular field of study $(39,40)$.

\section{CONCLUSIONS}

Sulfated glycoconjugates are linked to the development, transmission and survival of Plasmodium in its intermediate and definitive hosts. A better understanding of the role of sulfated glycoconjugates in malaria infection will permit the identification of new therapeutic strategies for individuals who suffer from the disease and its complications and facilitate blocking of parasite transmission and/or successful infection in humans. The mechanism used by the parasite to sense the sulfate concentration in both HS and CS in different tissues in mosquitoes and humans and to accomplish the adhesion and invasion processes must be determined.

\section{List of abbreviations}

Glc-Nac: N-acetylglucosamine

Gal-Nac: N-acetylgalactosamine

PfEMP-1: Plasmodium falciparum erythrocyte membrane protein 1

pRBCs: parasitized red blood cells

HS: heparan sulfate

CS: chondroitin sulfate

CSA: chondroitin sulfate A

ICAM-1: intercellular adhesion molecule 1

\section{Conflicts of Interest}

The authors declare they have no conflicts of interest.

\section{Authors' contributions statement}

Idea conception: E. Garrido and L.C. Burgos; acquisition of data: E. Garrido and L. C. Burgos; analysis and interpretation: E. Garrido; drafting: E. Garrido and L. Rocha. All authors subsequently read, revised and approved the manuscript.

\section{ACKNOWLEDGEMENTS}

We express our gratitude to the Corporación Universitaria Remington and to Universidad de Antioquia for giving us the time needed to prepare this review. 


\section{REFERENCES}

1. Alam A. Serine Proteases of Malaria Parasite Plasmodium falciparum: Potential as Antimalarial Drug Targets. Hindawi Publ Corp. 2014; 2014:1-7.

2. Houzé S, Hoang N-T, Lozach O, Le Bras J, Meijer L, Galons H, et al. Several human cyclin-dependent kinase inhibitors, structurally related to roscovitine, as new anti-malarial agents. Molecules [Internet]. 2014 Jan [cited 2014 Dec 2]; 19(9):15237-57.

3. Gardner MJ, Hall N, Fung E, White O, Berriman M, Hyman RW, et al. Genome sequence of the human malaria parasite Plasmodium falciparum. Nature [Internet]. 2002 Oct 3; 419(6906):498-511.

4. Susomboon P, Iwagami M, Tangpukdee N, Krusood S, Looareesuwan S, Kano S. Differences in genetic population structures of Plasmodium falciparum isolates from patients along Thai-Myanmar border with severe or uncomplicated malaria. Malar ] [Internet]. 2008 Jan [cited $2014 \mathrm{Dec}$ 2]; 7:212.

5. Tao D, Ubaida-Mohien C, Mathias DK, King JG, Pastrana-Mena R, Tripathi A, et al. Sex-partitioning of the Plasmodium falciparum Stage V Gametocyte Proteome Provides Insight into falciparum-specific Cell Biology. Mol Cell Proteomics [Internet]. 2014; 13(10):2705-24.

6. Khan SM, Franke-Fayard B, Mair GR, Lasonder E, Janse CJ, Mann M, et al. Proteome analysis of separated male and female gametocytes reveals novel sex-specific Plasmodium biology. Cell [Internet]. 2005 Jun 3 [cited 2014 Dec 2]; 121(5):675-87.

7. Chen $B Q$, Barragan A, Fernandez V, Sundström A, Schlichtherle $M$, Sahlén A, et al. Identification of Plasmodium falciparum Erythrocyte Membrane Protein 1 (PfEMP1) as the Rosetting Ligand of the Malaria. J Exp M. 1998;187(1):15-23.

8. von Itzstein M, Plebanski M, Cooke BM, Coppel RL. Hot, sweet and sticky: the glycobiology of Plasmodium falciparum. Trends Parasitol [Internet]. 2008 May [cited 2014 Dec 2]; 24(5):210-8.

9. Dinglasan RRMJ-L. Flipping the paradigm on malaria transmission-blocking vaccines. Trends Parasitol. $2008 ; 24(8): 364-70$.

10. Dinglasan RR, Alaganan A, Ghosh AK, Saito A, van Kuppevelt TH, Jacobs-Lorena M. Plasmodium falciparum ookinetes require mosquito midgut chondroitin sulfate proteoglycans for cell invasion. Proc Natl Acad Sci U S A [Internet]. 2007 Oct 2; 104(40):15882-7.

11. Pinzon-Ortiz C1, Friedman J, Esko J SP. The binding of the circumsporozoite protein to cell surface heparan sulfate proteoglycans is required for plasmodium sporozoite attachment to target cells. J Biol Chem. 2014; 276(29):26784-91.

12. MacPherson GG, Warrell MJ, White NJ, Looareesuwan S, Warrell DA. Human cerebral malaria. A quantitative ultrastructural analysis of parasitized erythrocyte sequestration. Am J Pathol. 1985; 119(3):385-401.

13. Bannister LH, Sherman IW. Plasmodium. Encycl Life Sci. 2009; (December):1-12.

14. Mathews, CK; Van Holde, KE; Ahern KG. Biochemistry. 3rd ed. Madrid, Spain: Wesley; 2002. 335-48 p.

15. Brooks S, Schumacher U. Functional and Molecular Glycobiology. First. Oxford, UK: BIOS Scientific Publishers Ltd; 2002. 160-9 p.

16. Chappell D, Jacob M, Becker BF, Hoffmann-Kiefer K, Conzen P. Expedition glycocalyx. A newly discovered "Great Barrier Reef". Anaesthesist. 2008; 57(10):959-69.

17. Esko JD, Selleck SB. Order out of chaos: assembly of ligand binding sites in heparan sulfate. Annu Rev Biochem. 2002; 71:435-71.

18. Cohen $M$, Hurtado-Ziola N, Varki A. ABO blood group glycans modulate sialic acid recognition on erythrocytes. Blood. 2009; 114(17):3668-76.

19. Anstee DJ. The relationship between blood groups and disease. Blood. 2010; 115:4635-43. 
Heparan sulfate and chondroitin sulfate: general aspects of their participation during Plasmodium falciparum...

20. Barragan A, Kremsner PG, Wahlgren M, Carlson J. Blood group A antigen is a coreceptor in Plasmodium falciparum rosetting. Infect Immun [Internet]. 2000 May; 68(5):2971-5.

21. Achur RN, Valiyaveettil M, Alkhalil A, Ockenhouse CF, Gowda DC. Characterization of proteoglycans of human placenta and identification of unique chondroitin sulfate proteoglycans of the intervillous spaces that mediate the adherence of Plasmodium falciparum-infected erythrocytes to the placenta. J Biol Chem [Internet]. 2000 Dec 22 [cited 2014 Dec 2]; 275(51):40344-56.

22. Mota MM, Rodriguez A. Migration through host cells: the first steps of Plasmodium sporozoites in the mammalian host. Cell Microbiol [Internet]. 2004 Dec [cited 2014 Dec 2]; 6(12):1113-8.

23. Rennenberg A, Lehmann C, Heitmann A, Witt T, Hansen G, Nagarajan K, et al. Exoerythrocytic Plasmodium parasites secrete a cysteine protease inhibitor involved in sporozoite invasion and capable of blocking cell death of host hepatocytes. PLoS Pathog [Internet]. 2010 Mar [cited 2014 Dec 2];6(3):e1000825.

24. Coppi A, Tewari R, Bishop JR, Bennett BL, Lawrence R. Heparan sulfate proteoglycans provide a signal to Plasmodium sporozoites to stop migrating and productively invade host cells. Cell Host Microbe. 2008; 2(5):316-27.

25. Srivastava A, Gangnard S, Round A, Dechavanne S, Juillerat A, Raynal B, et al. Full-length extracellular region of the var2CSA variant of PfEMP1 is required for specific, high-affinity binding to CSA. Proc Natl Acad Sci U S A [Internet]. 2010 Mar 16 [cited 2014 Dec 2]; 107(11):4884-9.

26. Vogt AM, Barragan A, Chen Q, Kironde F, Spillmann D, Wahlgren M. Heparan sulfate on endothelial cells mediates the binding of Plasmodium falciparum - infected erythrocytes via the DBL1 domain of PfEMP1. Blood. 2003; 101(6):2405-11.

27. Fried M, Duffy P. Adherence of Plasmodium falciparum to chondroitin sulfate $A$ in the human placenta. Science (80- ) [Internet]. 1996 [cited 2014 Jun 17]; 272(June):1502-4.

28. Valiyaveettil M, Achur RN, Alkhalil A, Ockenhouse CF, Gowda DC. Plasmodium falciparum cytoadherence to human placenta: evaluation of hyaluronic acid and chondroitin 4-sulfate for binding of infected erythrocytes. Exp Parasitol [Internet]. 2001; 99(2):57-65.

29. Beeson JG, Rogerson SJ, Brown G V. Evaluating specific adhesion of Plasmodium falciparum-infected erythrocytes to immobilised hyaluronic acid with comparison to binding of mammalian cells. Int J Parasitol [Internet]. 2002 Sep; 32(10):1245-52.

30. Rogerson S, Chaiyaroj S. Chondroitin sulfate A is a cell surface receptor for Plasmodium falciparuminfected erythrocytes. J Exp Med [Internet]. 1995 [cited 2014 May 20]; 182(July):15-20.

31. Barragan A, Spillmann D, Kremsner PG, Wahlgren M, Carson J. Plasmodium falciparum: molecular background to strain-specific rosette disruption by glycosaminoglycans and sulfated glycoconjugates. Exp Parasitol. 1999; 91(2):133-43.

32. Jones CJ AJ. Glycosylation at the fetomaternal interface: does the glycocode play a critical role in implantation? Glycoconj J. 2009; 26(3):359-66.

33. Garrido E. Glicosaminoglicanos como posibles reguladores de inflamación durante la malaria placentaria. Rev Chil Obstet Ginecol [Internet]. 2014; 79(4):288-93.

34. Sinnis $P$, Coppi $A$, Toida $T$, Toyoda $H$, Kinoshita A. Mosquito heparan sulfate and its potential role in malaria infection and transmission. J Biol Chem. 2007; 282(35):25376-84.

35. Atkinson SC, Armistead JS, Mathias K., Sandeu MM, Tao D, Borhani-Dizaji N, et al. Structural analysis of Anopheles midgut aminopeptidase $\mathrm{N}$ reveals a novel malaria transmission-blocking vaccine $\mathrm{B}$-cell epitope. Nat Struct Mol Biol. 2015; 22(7):532-9.

36. Landoni M, Duschak VG., Peres VJ., Nonami H, Erra-Balsells R, Katzin A, et al. Plasmodium falciparum biosynthesizes sulfoglycosphingolipids. Mol Biochem Parasitol. 2007; 154(1):22-9.

37. Shams-Eldina H, Santos de Macedo C, Niehus S, Dorna C, Kimmel J., Azzouz N, et al. Plasmodium falciparum dolichol phosphate mannose synthase represents a novel clade. Biochem Biophys Res Comun. 2008; 370(3):388-93. 
38. Leitgeb AM, Blomqvist K, Cho-Ngwa F, Samje M, N de P, Titanji V, et al. Low anticoagulant heparin disrupts Plasmodium falciparum rosettes in fresh clinical isolates. Am J Trop Med Hyg [Internet]. 2011 Mar [cited 2016 May 12]; 84(3):390-6.

39. Valle-Delgado JJ, Urbán $P$, Fernàndez-Busquets $X$. Demonstration of specific binding of heparin to Plasmodium falciparum-infected vs. non-infected red blood cells by single-molecule force spectroscopy. Nanoscale [Internet]. 2013;5(9):3673-80.

40. Marques J, Moles E, Urban P, Prohens R, Busquets MA, Sevrin C, et al. Application of heparin as a dual agent with antimalarial and liposome targeting activities toward Plasmodium-infected red blood cells. Nanomedicine Nanotechnology, Biol Med [Internet]. 2014; 10(8):1719-28. 